\title{
IMPLIKASI YURIDIS KEDUDUKAN ALAT BUKTI ELEKTRONIK DALAM PERKARA PIDANA PASCA PUTUSAN MAHKAMAH KONSTITUSI NOMOR 20/PUU-XIV/2016
}

\author{
${ }^{1}$ Hanafi; ${ }^{2}$ Muhammad Syahrial Fitri \\ Fakultas Hukum Universitas Islam Kalimantan MAB \\ Jl. Adhyaksa No. 2 Kayutangi, Banjarmasin, Kalimantan Selatan \\ ${ }^{1}$ Email: hanafiramsi@gmail.com; \\ ${ }^{2}$ Email: iyal_888@yahoo.co.id
}

\begin{abstract}
The purpose of this research is, first to analyze the strength of electronic proof tool proving in the criminal matter proving system in Indonesia, second to analyze the jurisdiction of the juridical position of electronic evidence post verdict of the Constitutional Court No. 20/PUU$\mathrm{XIV} / 2016$ in criminal matters in Indonesia. This research is a normative legal research that examines and examines the legislation related to the use of electronic evidence tools in the system of proof of criminal matters in Indonesia, as well as the verdict of the Constitutional Court No. 20/PUU-XIV/2016 which is the basis of the footing in conducting this research. The results of research can be concluded that the first, the existence of electronic evidence tools/electronic documents have an important role in proving a criminal case, but should pay attention to three aspects that are related to authenticity (originality), related to its content (substance), and related to other evidence that can strengthen the electronic evidence tool. Second, the juridical implications of the position of electronic evidence post-ruling Constitutional Court No. 20/PUU-XIV/2016 in criminal matters in Indonesia is that all electronic evidence instruments/electronic documents cannot be used as evidence if not conducted in the framework of law enforcement at the request of the police, prosecutors, and/or other law enforcement institutions stipulated by law, then all electronic information as a means of evidence in the proceeding shall become invalid.
\end{abstract}

Keywords: juridical implications, electronic evidence tools, criminal matters.

\begin{abstract}
Abstrak
Hal yang menjadi tujuan dari penelitian ini adalah, pertama untuk menganalisis kekuatan pembuktian alat bukti elektronik dalam sistem pembuktian perkara pidana di Indonesia, kedua untuk menganalisis implikasi yuridis kedudukan alat bukti elektronik pasca putusan Mahkamah Konstitusi Nomor 20/PUU-XIV/ 2016 dalam perkara pidana di Indonesia. Penelitian ini merupakan penelitian hukum normatif yang meneliti dan mengkaji peraturan perundang-undangan yang terkait dengan penggunaan alat bukti elektronik dalam sistem pembuktian perkara pidana di Indonesia, juga putusan Mahkamah Konstitusi Nomor 20/PUU-XIV/ 2016 yang menjadi dasar pijakan dalam melakukan penelitian ini. Hasil penelitian menunjukan bahwa pertama, keberadaan alat bukti elektronik / dokumen
\end{abstract}


elektronik memiliki peran penting dalam pembuktian suatu perkara pidana, namun harus memperhatikan tiga aspek yaitu terkait dengan keasliannya (originalitas), terkait dengan isinya (substansi), dan terkait dengan alat bukti lain yang dapat memperkuat alat bukti elektronik tersebut. Kedua, Implikasi yuridis kedudukan alat bukti elektronik pasca putusan Mahkamah Konstitusi Nomor 20/PUU-XIV/2016 dalam perkara pidana di Indonesia adalah bahwa semua alat bukti elektronik / dokumen elektronik tidak dapat dijadikan alat bukti jika tidak dilakukan dalam rangka penegakan hukum.

Kata kunci: Implikasi Yuridis, Alat Bukti Elektronik, Perkara Pidana.

\section{PENDAHULUAN}

Pembuktian dalam perkara pidana memiliki peranan yang sangat penting terutama dengan kemampuan hakim untuk merekontruksi peristiwa atau kejadian masa lalu sebagai suatu kebenaran. Tujuan pembuktian ialah untuk mencari suatu kebenaran secara materil atau setidak-tidaknya mendekati kebenaran yang selengkap-lengkapnya. ${ }^{1}$

Hukum pembuktian merupakan sebagian dari hukum acara pidana yang mengatur macam-macam alat bukti yang sah menurut hukum, sistem yang dianut dalam pembuktian, syarat-syarat dan tata cara mengajukan bukti tersebut serta

\footnotetext{
1 Kadi Sukarna. 2014. Alat Bukti Petunjuk dalam Proses Peradilan Pidanal Prosiding Seminar Nasional: Pengembangan Epistemologi Ilmu Hukum). Surabaya: Untag 45 Hlm. 351.
}

kewenangan hakim untuk menerima, menolak dan menilai suatu pembuktian. ${ }^{2}$

Alat Pembuktian yang sah
menurut undang-undang adalah
berdasarkan Pasal 184 Kitab Undang-
Undang Hukum Acara Pidana (selanjutnya
disebut dengan KUHAP) yang menentukan
bahwa alat bukti terdiri atas:

1. Keterangan saksi;

2. Keterangan ahli;

3. Surat;

4. Petunjuk;

5. Keterangan terdakwa; ${ }^{3}$

Menurut Yahya Harahap, dalam buku Pembahasan, Permasalahan, dan Penerapan KUHAP: Pemeriksaan Sidang Pengadilan, Banding, Kasasi, dan Peninjauan Kembali, Pasal 184 ayat (1) KUHAP telah menentukan secara "limitatif" alat bukti yang sah menurut

\footnotetext{
${ }^{2}$ Hari Sasangka dan Lily Rosita. 2003. Hukum Pembuktian Dalam Perkara Pidana. Bandung: Mandar Maju. HIm. 10.

3 Ketentuan Pasal 184 Kitab Undang-Undang Hukum Acara Pidana.
} 
undang-undang. Di luar alat bukti itu, tidak dibenarkan dipergunakan untuk membuktikan kesalahan terdakwa. Ketua sidang, penuntut umum, terdakwa atau penasihat hukum, terikat dan terbatas hanya diperbolehkan mempergunakan alatalat bukti itu saja. Mereka tidak leluasa mempergunakan alat bukti yang dikehendakinya di luar alat bukti yang ditentukan Pasal 184 ayat (1) KUHAP. Yang dinilai sebagai alat bukti, dan yang dibenarkan mempunyai "kekuatan pembuktian" hanya terbatas kepada alatalat bukti itu saja. Pembuktian dengan alat bukti di luar jenis alat bukti itu, tidak mempunyai nilai serta tidak mempunyai kekuatan pembuktian yang mengikat. Sehingga hal ini menimbulkan suatu pemasalahan yaitu bagaimana dengan alat

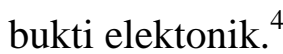

Sebelum disahkannya UndangUndang tentang Informasi dan Transaksi Elektronik, salah satu hal yang menjadi kendala dalam penanganan praktik tindak pidana dunia maya ini adalah bahwa buktibukti berupa software, data elektronik, atau data dalam bentuk elektronik (elektronik evidence) lainnya yang belum dapat diterima sebagai alat bukti dalam hukum

\footnotetext{
4 Yahya Harahap. 2007. Pembahasan, Permasalahan, dan Penerapan KUHAP: Pemeriksaan Sidang Pengadilan, Banding, Kasasi, dan Peninjauan Kembali. Jakarta: Sinar Grafika. Hlm. 15.
}

Indonesia. Sementara berdasarkan Pasal 28 Ayat (1) Undang-Undang Republik Indonesia Nomor 4 Tahun 2004 tentang Kekuasaan Kehakiman, bahwa hakim wajib menggali, mengikuti, dan memahami nilai-nilai hukum dan rasa keadilan yang hidup dalam masyarakat. Dengan demikian, maka hakim wajib menggali, mengikuti, dan memahami nilai-nilai hukum dan rasa keadilan yang hidup dalam masyarakat, dalam hal ini menyangkut halhal yang berkaitan dengan eksistensi alat bukti elektronik dalam menangani praktik tindak pidana dunia maya terhadap transaksi elektronik. ${ }^{5}$

Dalam Undang-Undang No. 11 Tahun 2008 tentang Informasi dan Transaksi Elektronik (selanjutnya disebut dengan UU ITE) sebagai suatu norma hukum khusus terdapat suatu prinsipprinsip hukum baru, diluar dari sistem hukum yang ada sebagaimana diatur dalam KUHP maupun KUHAP. Salah satunya adalah mengenai alat bukti elektronik yang baru diakui sebagai suatu alat bukti yang sah dalam hukum pembuktian di Indonesia.

\section{Sejak diundangkannya UU ITE} maka terdapat penambahan jenis alat bukti

5 Sahuri Lasmadi. 2014. Pengaturan Alat Bukti Dalam Tindak Pidana Dunia Maya. Jurnal Ilmu Hukum Volume 5 No. 2. Oktober 2014. HIm. 2. 
di persidangan yakni informasi elektronik dan/atau dokumen elektronik. Dalam ketentuan umum UU ITE dapat diketahui bahwa jenis data elektronik seperti tulisan, foto, suara, gambar merupakan informasi elektronik sedangkan jenis informasi elektronik seperti tulisan, foto, suara, gambar yang disimpan pada flash disk yang dapat dibuka melalui perangkat komputer merupakan dokumen elektronik.

\section{Bermula dari kasus Setya} Novanto (selaku pemohon) pada tanggal 10 Februari 2016 melalui kuasa hukumnya melakukan uji materiil (judicial review) terhadap Undang-Undang ITE dan Undang-undang Tipikor ke Mahkamah Konstitusi, ia mempersoalkan pasal-pasal yang berada dalam dua undang-undang tersebut yang dinilai bertentangan dengan Undang-Undang Dasar 1945 (UUD 1945), adapun pasal-pasal yang diujikan adalah pasal 5 ayat (1), pasal 5 ayat (2) dan pasal 44 huruf b UU Nomor 11 Tahun 2008 tentang Informasi dan Transaksi Elektronik (UU ITE) dan Pasal 26A UU Nomor 26 tahun 2001 tentang perubahan atas undang-undang nomor 31 tahun 1999 tentang Pemberantasan Tindak Pidana Korupsi.

Adapun Mahkamah Konstitusi dalam amar putusannya yang dibacakan pada tanggal 7 September 2016 ialah mengabulkan permohonan pemohon untuk sebagian, yang mana seluruh pasal 5 ayat (1) dan (2) dan pasal 44 huruf b UU ITE dan pasal 26A UU Tipikor ialah bertentangan dengan Undang-Undang Dasar 1945 sepanjang tidak dimaknai khususnya frasa "Informasi Elektronik dan/atau Dokumen Elektronik" sebagai alat bukti dalam rangka penegakan hukum atas permintaan kepolisian, kejaksaan, dan/atau institusi penegak hukum lainnya yang ditetapkan berdasarkan undang-undang sebagaimana ditentukan dalam pasal 31 ayat (3) Undang-Undang Nomor 11 Tahun 2008 tentang Informasi dan Transaksi Elektronik.

Putusan ini menjadi masalah serius jika dikaitkan dengan penegakan hukum kasus-kasus pidana yang berkaitan dengan alat bukti elektronik baik berupa informasi elektronik ataupun dokumen elektronik. Seiring dengan berkembangnya teknologi, maka mulai bermunculan alatalat yang dapat membantu kepolisian/kejaksaan dalam melakukan pembuktian di pengadilan. Salah satu contoh ialah closed-circuit television atau yang lazim disebut CCTV yang biasa digunakan oleh masyarakat dalam memantau kondisi keamanan sekitar. Tujuan dipasangkannya CCTV ialah agar 
terpantaunya keaman disekitaran suatu tempat, dan apabila ada tindak pidana yang terjadi, maka bukti rekaman yang ada dalam CCTV tadi dapat dijadikan bukti bahwa telah terjadi suatu tindak pidana, sehingga memudahkan penyidik dalam membuktikan tindak pidana yang terjadi, walaupun tidak ada saksi yang melihat, mendengar dan merasakan secara langsung suatu peristiwa pidana.

\section{RUMUSAN MASALAH}

Berdasarkan latar belakang masalah diatas, maka dapat dirumusakan suatu rumusan masalah yang akan diteliti yaitu sebagai berikut:

1. Bagaimana kekuatan pembuktian alat bukti elektronik dalam sistem pembuktian perkara pidana di Indonesia?

2. Bagaimana implikasi yuridis kedudukan alat bukti elektronik pasca putusan Mahkamah Konstitusi Nomor 20/PUU-XIV/ 2016 dalam perkara pidana di Indonesia?

\section{METODE PENELITIAN}

Penelitian ini dilakukan dengan jenis penelitian hukum normatif, yaitu penelitian kepustakaan yang menggunakan 3 bahan hukum yaitu bahan hukum primer, bahan hukum sekunder dan bahan hukum tersier. Penelitian ini menitikberatkan pada studi kepustakaan yang dalam pengkajiannya mengacu dan mendasarkan pada norma-norma, kaidah-kaidah hukum, peraturan perundang-undangan yang berlaku, teori-teori dan doktrin hukum, yurisprudensi, dan bahan-bahan kepustakaan lainnya yang relevan dengan topik penelitian.

Pengumpulan bahan hukum dilakukan dengan studi pustaka yakni melalui pengakajian terhadap Kitab Undang-Undang Hukum Acara Pidana (KUHAP) dan Undang Undang Nomor 11 Tahun 2008 Tentang Informasi dan Transaksi Elektronik (UU ITE) serta berbagai pustaka yang relevan dengan objek penelitian.

Pendekatan penelitian yang peneliti pergunakan dalam penelitian ini adalah pendekatan statute approach yaitu pendekatan peraturan perundang-undangan yang menitikberatkan pada bahan hukum primer yang mengatur tentang alat bukti elektronik dalam sistem pembuktian perkara pidana di Indonesia .

Analisis bahan hukum yang digunakan dalam penelitian ini adalah dengan metode kualitatif, yaitu bahan hukum yang telah terkumpul dari studi dokumen dikelompokkan sesuai dengan permasalahan yang akan dibahas. Bahan 
hukum tersebut kemudian ditafsirkan dan dianalisis guna mendapatkan kejelasan (pemecahan dari masalah yang akan dibahas). Dengan kata lain analisis bahan hukum dengan metode ini akan menemukan suatu kesimpulan yang dituangkan dalam bentuk pernyataan atau tulisan.

\section{PEMBAHASAN}

\section{Kekuatan Pembuktian Alat Bukti Elektronik Dalam Sistem Pembuktian Perkara Pidana di Indonesia}

Dalam konteks hukum acara pidana, pembuktian merupakan inti persidangan perkara pidana karena yang dicari dalam hukum acara pidana adalah kebenaran materiil, yang menjadi tujuan pembuktian adalah benar bahwa suatu tindak pidana telah terjadi dan terdakwalah yang bersalah melakukannya. ${ }^{6}$ Untuk membuktikan kesalahan terdakwa tersebut pengadilan melalui meja hakim terikat oleh cara-cara/ketentuan-ketentuan pembuktian sebagaimana diatur dalam undang-undang, termasuk berkaitan dengan alat bukti sebagaimana ketentuan dalam Pasal 184 ayat (1) KUHAP dan alat bukti elektronik sebagaimana diatur dalam Pasal 5 Undang-

6 Hanafi, Reza Aditya Pamuji. Urgensi Keterangan Ahli Sebagai Alat Bukti Berdasarkan Sistem Peradilan Pidana di Indonesia. Jurnal Al'Adl Volume 10 Nomor 1, Januari 2019. Hlm. 84.
Undang Nomor 11 Tahun 2008 (UU ITE). Dalam Pasal 183 bahwa hakim tidak boleh menjatuhkan pidana kepada seseorang kecuali apabila dengan sekurangkurangnya dua alat bukti yang sah ia memperoleh keyakinan bahwa suatu tindak pidana benar-benar terjadi dan bahwa terdakwalah yang bersalah melakukannya

Dalam praktik hukum acara pidana kekuatan semua alat bukti pada dasarnya memiliki kekuatan pembuktian yang sama, tidak ada alat bukti yang satu melebihi alat bukti yang lain. Alat bukti dalam hukum pidana tidak mengenal istilah hierarki. ${ }^{7} \mathrm{Hal}$ ini dapat dimaknai bahwa pada prinsipnya antara alat bukti yang satu dengan alat bukti yang lain tidak memiliki daya penentu dan menentukan. ${ }^{8}$ Hanya saja ada ketentuan-ketentuan yang mensyaratkan keterkaitan antara bukti yang satu dengan bukti yang lain. Oleh karena itu, dalam hukum acara pidana terdapat bukti yang bersifat pelengkap.

Pada prinsipnya alat bukti elektronik tidak mempunyai nilai kekuatan yang mengikat dan menentukan. Dengan demikian nilai kekuatan pembuktian alat

\footnotetext{
7 Nur Laili Isma dan Arima Koyimatun. Kekuatan Pembuktian Alat Bukti Informasi Elektronik Pada Dokumen Elektronik Serta Hasil Cetaknya Dalam Pembuktian Tindak Pidana. Jurnal Penelitian Hukum Volume 1, Nomor 2, Juli 2014. Hlm. 112

${ }^{8}$ Op.cit. Hlm 87.
} 
bukti elektronik sama halnya dengan nilai kekuatan pembuktian alat bukti yang lain. Oleh karena itu, nilai kekuatan pembuktian yang melekat pada alat bukti elektronik yaitu:

a. Mempunyai nilai kekuatan pembuktian bebas atau vrij bewijskrachf.

Di dalam alat bukti elektronik tidak melekat nilai kekuatan pembuktian yang sempurna dan menentukan. Semua tergantung pada penilaian hakim, hakim bebas menilai dan tidak terikat kepada alat bukti tersebut. Tidak ada keharusan bagi hakim untuk mesti menerima apa yang ada di dalam alat bukti elektronik tersebut. Hakim dalam menggunakan wewenang kebenaran dalam penilaian pembuktian, harus benar-benar bertanggungjawab, atas landasan moral dan kebenaran sejati demi tegaknya hukum serta kepastian hukum.

b. Berlakunya prinsip minimum pembuktian pada alat bukti elektronik

Bahwa alat bukti elektronik saja tidak cukup membuktikan kesalahan seseorang, oleh karena itu alat bukti elektronik dapat dianggap cukup membuktian kesalahan seseorang harus disertai dengan alat bukti lain. ${ }^{9}$

Walaupun demikian dalam

9 Edmon Makarim, Kompilasi Hukum Telematika, PT Raja Grafindo Persada. Jakarta: 2004. Hlm. 435. pembuktian modern dikenal istilah alat bukti universal. Salah satu alat bukti universal di dunia ini adalah dokumen. Dokumen itu tercakup dokumen elektronik (alat bukti elektronik) termasuk didalamnya adalah hasil printout yang disebut juga merupakan dokumen, ataupun berupa gambar/foto beserta hasil cetaknya juga disebut sebagai dokumen. Alat bukti elektronik harus dilakukan verifikasi lebih lanjut karena alat bukti dokumen elektronik sama juga dengan verfikasi terhadap alat bukti surat. Ada tiga hal yang berkaitan dengan masalah ini, yaitu terkait dengan keasliannya (originalitas), terkait dengan isinya (substansi), dan terkait dengan mencari alat-alat bukti lain yang dapat memperkuat alat bukti dokumen elektronik tersebut.

Alat bukti elektronik sangat rentan untuk dimanipulasi. Sehingga keaslian alat bukti elektronik / dokumen elektronik sangat penting dalam pembuktian. Keabsahan dari alat bukti elektronik masih sangat diperlukan pembuktian lebih lanjut. Pembuktian ini terkait erat dengan originalitas alat bukti elektronik. Mengingat penilaian keabsahan alat bukti elektronik dan sangat sulit, karena jangan sampai keberadaan alat bukti elektronik merugikan orang lain. Selain masalah 
originalitas dari suatu alat bukti elektronik atau dokumen elektronik dalam menjadikan suatu data atau dokumen sebagai alat bukti yang sah dalam pembuktian perkara pidana adalah masalah pengambilan data yang bisa dijadikan alat bukti. Karena dalam pengambilan alat bukti tidak mudah. Alasan kedua, karena sampai saat ini belum ada Standard Operating Procedure (SOP) dalam pengambilan alat bukti elektronik. Padahal mengingat kasus- kasus yang bersinggungan dengan cyberspace atau sybercrime dan elektronik sudah berkembang. Mengingat yang bertugas untuk mengumpulkan alat bukti adalah penyidik, sehingga diperlukan dengan segera SOP dari penyidik kaitannya dengan pengambilan alat bukti informasi elektronik dan dokumen elektronik.

Tidak sembarang informasi elektronik dan/atau dokumen elektronik dapat dijadikan alat bukti yang sah. Menurut UU ITE, suatu informasi elektronik dan/atau dokumen elektronik dinyatakan sah untuk dijadikan alat bukti apabila menggunakan sistem elektronik yang sesuai dengan ketentuan yang diatur dalam UU ITE, yaitu sistem elektronik yang andal dan aman, serta memenuhi persyaratan minimum yaitu; dapat menampilkan kembali informasi elektronik dan/atau dokumen elektronik secara utuh sesuai dengan masa retensi yang ditetapkan dengan peraturan perundang-undangan, dapat melindungi ketersediaan, keutuhan, keotentikan, kerahasiaan, dan keteraksesan informasi elektronik dalam penyelenggaraan sistem elektronik tersebut, Dapat beroperasi sesuai dengan prosedur atau petunjuk dalam penyelenggaraan sistem elektronik tersebut, dilengkapi dengan prosedur atau petunjuk yang diumumkan dengan bahasa, informasi, atau simbol yang dapat dipahami oleh pihak yang bersangkutan dengan penyelenggaraan sistem elektronik tersebut; dan Memiliki mekanisme yang berkelanjutan untuk menjaga kebaruan, kejelasan, dan kebertanggungjawaban prosedur atau petunjuk. ${ }^{10}$

Dari paparan di atas maka dapat diambil kesimpulan bahwa dalam hal kekuatan pembuktian, hakim memiliki peranan penting dalam menilai kekuatan dari alat bukti elektronik. Meskipun telah dijelaskan sebelumnya bahwa dalam pembuktian pidana tidak mengenal hierarki alat bukti atau pembuktian bebas. Hakim memiliki hak untuk menilai alat bukti yang dihadirkan Mahkamah Konstitusi Nomor 20/PUU-XIV/2016 Terhadap Informasi Elektronik Dan/Atau Dokumen Elektronik Dan/Atau Hasil Cetaknya Sebagai Alat Bukti Dalam Perkara Perdata. Jurnal Rechtidee Volume 11, Nomor 2, Desember 2016. 
dalam persidangan. Hakim terikat dengan minimum pembuktian yaitu dalam menjatuhkan putusan hakim harus berdasarkan 2 alat bukti yang sah sebagaimana diatur dalam pasal 183 KUHAP. Sehingga keberadaan alat bukti elektronik / dokumen elektronik memiliki peran penting dalam pembuktian suatu perkara pidana.

\section{Implikasi Yuridis Kedudukan Alat} Bukti Elektronik Pasca Putusan Mahkamah Konstitusi Nomor 20/PUUXIV/2016 Dalam Perkara Pidana di Indonesia

Mahkamah Konstitusi Republik Indonesia pada tanggal 7 September 2016 telah menjatuhkan putusan dalam perkara Pengujian Undang-undang Nomor 11 Tahun 2008 Tentang Informasi dan Transaksi Elektronik dan Undang-undang Nomor 20 Tahun 2001 Tentang Perubahan Atas Undang-undang Nomor 31 Tahun 1999 Tentang Pemberantasan Tindak Pidana Korupsi Terhadap Undang-Undang Dasar Negara Republik Indonesia yang dimohonkan oleh Setya Novanto.

Perkara tersebut bermula dari keberatan pihak pemohon atas rekaman suaranya yang dipakai sebagai bukti. Dalam putusannya Mahkamah Konstitusi dalam amar putusannya ialah mengabulkan permohonan pemohon untuk sebagian, yang mana seluruh pasal 5 ayat (1) dan (2) dan pasal 44 huruf b UU ITE dan pasal 26A UU Tipikor ialah bertentangan dengan Undang-Undang Dasar 1945 sepanjang tidak dimaknai khususnya frasa "Informasi Elektronik dan/atau Dokumen Elektronik" sebagai alat bukti dalam rangka penegakan hukum atas permintaan kepolisian, kejaksaan, dan/atau institusi penegak hukum lainnya yang ditetapkan berdasarkan undangundang sebagaimana ditentukan dalam pasal 31 ayat (3) Undang-Undang Nomor 11 Tahun 2008 tentang Informasi dan Transaksi Elektronik.

Pasca Putusan Mahkamah Konstitusi Nomor 20/PUU-XIV/2016 terkait dengan Pasal tentang Pasal 5 ayat (1) dan ayat (2) dan Pasal 44 huruf b Undang-Undang Nomor 8 Tahun 2008 tentang Informasi dan Transaksi Elektronik (UU ITE), serta Pasal 26A UndangUndnag No 29 Tahun 2001 maka dibutuhkan pengaturan kembali tentang kedudukan bukti elektronik dan prosedur perolehannya dalam sistem peradilan pidana Indonesia.

Sebelumnya dalam UU ITE dinyatakan bahwa:

\section{Pasal 5}


1) Informasi Elektronik dan/atau Dokumen Elektronik dan/atau hasil cetaknya merupakan alat bukti hukum yang sah.

2) Informasi Elektronik dan/atau Dokumen Elektronik dan/atau hasil cetaknya sebagaimana dimaksud pada ayat (1) merupakan perluasan dari alat bukti yang sah sesuai dengan Hukum Acara yang berlaku di Indonesia.

\section{Pasal 44}

Alat bukti penyidikan, penuntutan dan pemeriksaan di sidang pengadilan menurut ketentuan Undang-Undang ini adalah sebagai berikut:

b. alat bukti lain berupa Informasi Elektronik dan/atau Dokumen Elektronik sebagaimana dimaksud dalam Pasal 1 angka 1 dan angka 4 serta Pasal 5 ayat (1), ayat (2), dan ayat (3)

\section{Mahkamah Konstitusi telah} menyatakan frasa "informasi elektronik dan/atau dokumen elektronik" dalam Pasal Pasal-pasal diatas bertentangan dengan UUD 1945 . Mahkamah Konstitusi kemudian mengganti frasa tersebut menjadi "Khususnya Informasi Elektronik dan/atau dokumen elektronik sebagai alat bukti dilakukan dalam rangka penegakan hukum atas permintaan kepolisian, kejaksaan, dan/atau institusi penegak hukum lainnya yang ditetapkan berdasarkan undang-undang sebagaimana ditentukan dalam Pasal 31 ayat (3) UU No 11 Tahun 2008 tentang informasi dan Transaksi Elektronik"

Sehingga pasal-pasal tersebut harus di baca menjadi:

\section{Pasal 5}

1) Khususnya Informasi Elektronik dan/atau dokumen elektronik sebagai alat bukti dilakukan dalam rangka penegakan hukum atas permintaan kepolisian, kejaksaan, dan/atau institusi penegak hukum lainnya yang ditetapkan berdasarkan undang-undang sebagaimana ditentukan dalam Pasal 31 ayat (3) UU No 11 Tahun 2008 tentang informasi dan Transaksi Elektronik dan/atau hasil cetaknya merupakan alat bukti hukum yang sah.

2) Khususnya Informasi Elektronik dan/atau dokumen elektronik sebagai alat bukti dilakukan dalam rangka penegakan hukum atas permintaan kepolisian, kejaksaan, dan/atau institusi penegak hukum lainnya yang ditetapkan berdasarkan undang-undang sebagaimana ditentukan dalam Pasal 31 ayat (3) UU No 11 Tahun 2008 tentang informasi dan 
Transaksi Elektronik dan/atau hasil cetaknya sebagaimana dimaksud pada ayat (1) merupakan perluasan dari alat bukti yang sah sesuai dengan Hukum Acara yang berlaku di Indonesia

\section{Pasal 44}

Alat bukti penyidikan, penuntutan dan pemeriksaan di sidang pengadilan menurut ketentuan Undang-Undang ini adalah sebagai berikut:

b. alat bukti lain berupa Khususnya Informasi Elektronik dan/atau dokumen elektronik sebagai alat bukti dilakukan dalam rangka penegakan hukum atas permintaan kepolisian, kejaksaan, dan/atau institusi penegak hukum lainnya yang ditetapkan berdasarkan undang-undang sebagaimana ditentukan dalam Pasal 31 ayat (3) UU No 11 Tahun 2008 tentang informasi dan Transaksi Elektronik sebagaimana dimaksud dalam Pasal 1 angka 1 dan angka 4 serta Pasal 5 ayat (1), ayat (2), dan ayat (3)

Jika dianalisis amar putusan Mahkamah Konstitusi ini bahwa semua "Informasi Elektronik dan/atau Dokumen Elektronik tidak dapat dijadikan alat bukti jika tidak dilakukan dalam rangka penegakan hukum atas permintaan kepolisian, kejaksaan, dan/atau institusi penegak hukum lainnya yang ditetapkan berdasarkan undang-undang", maka semua informasi elektronik sebagai alat bukti dalam persidangan menjadi tidak sah, jika perekaman yang dilakukan tidak atas permintaan kepolisian, kejaksaan dan/atau institusi penegak hukum lainnya yang ditetapkan berdasarkan UndangUndang.

Putusan Mahkamah Konstitusi ini akan mengubah status dari informasi elektronik dan dokumen elektronik dalam penegakan hukum pidana yang akibatnya maka seluruh informasi elektronik/dokumen elektronik yang dapat menjadi bukti harus diperoleh berdasarkan prosedur sesuai pasal 31 ayat (3) UU ITE diluar itu maka informasi elektronik/ dokumen elektronik tidak diperbolehkan sebagai alat bukti.

Sehingga implikasi yuridisnya adalah bahwa di satu sisi hal ini positif bagi penegakan hukum penyadapan di Indonesia, karena penyadapan dan rekamannya jika dijadikan sebagai bukti haruslah sesuai dengan undang-undang. Namun di sisi lain, kondisi ini justru mempersempit penggunaan informasi elektronik/dokumen elektronik dalam penegakan hukum. Karena Mahkamah Konstitusi terlihat menyamakan pengertian intersepsi, penyadapan dengan 
perekaman (elektonik). Dalam konteks hukum intersepsi dan penyadapan apa yang menjadi pertimbangan Mahkamah Konstitusi cukup tepat, namun dalam situasi merekam atau perekaman informasi, oleh individu maka pertimbangan Mahkamah Konstitusi jauh melampaui situasi yang diharapan dalam penegakan hukum pidana.

Dalam perkara-perkara tindak pidana ke depan, maka seluruh dokumen elektronik/informasi elektronik dalam penegakan hukum pidana tidak dapat digunakan sebagai bukti/petunjuk jika tidak memenuhi syarat yang di putuskan oleh Mahkamah Konstitusi.

\section{PENUTUP}

Adapun dalam hasil penelitian ini dapat disimpulkan bahwa:

1. Kekuatan pembuktian alat bukti elektronik dalam sistem pembuktian perkara pidana di Indonesia pada prinsipnya bahwa alat bukti elektronik tidak mempunyai nilai kekuatan yang mengikat dan menentukan. Dengan demikian nilai kekuatan pembuktian alat bukti elektronik sama halnya dengan nilai kekuatan pembuktian alat bukti yang lain.

Oleh karena itu, nilai kekuatan pembuktian yang melekat pada alat bukti elektronik yaitu Mempunyai nilai kekuatan pembuktian bebas atau vrij bewijskrachf dan berlakunya prinsip minimum pembuktian pada alat bukti elektronik. Walaupun demikian keberadaan alat bukti elektronik / dokumen elektronik memiliki peran penting dalam pembuktian suatu perkara pidana, namun harus memperhatikan tiga aspek yaitu terkait dengan keasliannya (originalitas), terkait dengan isinya (substansi), dan terkait dengan mencari alat-alat bukti lain yang dapat memperkuat alat bukti dokumen elektronik tersebut.

2. Implikasi yuridis kedudukan alat bukti elektronik pasca putusan Mahkamah Konstitusi Nomor 20/PUU-XIV/2016 dalam perkara pidana di Indonesia adalah bahwa semua informasi elektronik/ dokumen elektronik tidak dapat dijadikan alat bukti jika tidak dilakukan dalam rangka penegakan hukum atas permintaan kepolisian, kejaksaan, dan/atau institusi penegak hukum lainnya yang ditetapkan berdasarkan undang-undang, maka semua 
informasi elektronik sebagai alat bukti dalam persidangan menjadi tidak sah, jika perekaman yang dilakukan tidak atas permintaan kepolisian, kejaksaan dan/atau institusi penegak hukum lainnya yang ditetapkan berdasarkan Undang-Undang. Putusan Mahkamah Konstitusi ini akan mengubah status dari informasi elektronik dan dokumen elektronik dalam penegakan hukum pidana yang akibatnya maka seluruh informasi elektronik/dokumen elektronik yang dapat menjadi bukti harus diperoleh berdasarkan prosedur sesuai pasal 31 ayat (3) UU ITE, di luar itu maka informasi elektronik/dokumen elektronik tidak diperbolehkan sebagai alat bukti.

\section{DAFTAR PUSTAKA}

\section{Buku}

Atmasasmita, Romli ,1996, Sistem Peradilan Pidana Indonesia. Jakarta: Alumni Bandung.

Adji, Oemar Seno, 1980, Peradilan Bebas Negara Hukum, Jakarta: PT. Erlangga

Azhary, 1995, Negara Hukum IndonesiaAnalisis Yuridis Normatif Tantang Unsur-unsurnya, Cet. Pertama, Jakarta: UI Press
Hakim, Abdul Aziz, 2011, Negara Hukum dan Demokrasi Di Indonesia, Yogyakarta: Penerbit Pustaka Pelajar

Harahap, Yahya. 2007, Pembahasan, Permasalahan, dan Penerapan KUHAP: Pemeriksaan Sidang Pengadilan, Banding, Kasasi, dan Peninjauan Kembali. Jakarta: Sinar Grafika.

Johan Nasution, Bahder, 2013, Negara Hukum dan Hak Asasi Manusia, Bandung: Mandar Maju.

Makarim, Edmon . 2004. Kompilasi Hukum Telematika. Jakarta: PT Raja Grafindo Persada.

M.P.Pangaribuan, Luhut 1996 Advokat dan Contemp of Court,Satu Profesi di Dewan Kehormatan Profesi, Jakarta: Djambatan

Muhammad, Abdul Kdir, 2006, Etika Profesi Hukum, cetakan ke-3, Bandung: Citra Aditya Bhakti.

Ranawijaya, Usep, 1983, Hukum Tata Negara Dasar-Dasarnya, Jakarta: Ghalia Indonesia

Rambe, Ropaun, 2001, Teknik Praktek Advokat, Jakarta : PT Gramedia Widiasarana Indonesia

Sasangka, Hari dan Lily Rosita, 2003, Hukum Pembuktian Dalam Perkara Pidana Untuk Mahasiswa dan Praktisi, Bandung: Mandar Maju

Soekanto, Soerjono, 1983, Faktor-faktor Yang Mempengaruhi Penegakkan Hukum, Cet. Pertama Jakarta : CV. Rajawali. 
Schmid, Von, 1988, Ahli-Ahli Pikir Besar Tentang Negara dan Hukum, Cetakan Keenam, Jakarta: PT. Pembangunan

Sunny, Ismail, 1982, Mencari Keadilan, Jakarta: PT. Ghalia Indonesia

Termorshuizen, Marjanne, 1999, Kamus Hukum Belanda - Indonesia, Jakarta: Djambatan

Yamin, Muh. 1982, Proklamasi dan Konstitusi Republik Indonesia, Jakarta: PT. Ghalia Indonesia,

Qamar, Nurul 2013, Hak Asasi Manusia dalam Negara Hukum Demokrasi, Jakarta: Sinar Grafika

\section{Peraturan Perundang-Undangan}

Republik Indonesia, Undang-Undang Dasar Negara Republik Indonesia Tahun 1945.

Republik Indonesia, Undang-Undang Tentang Hukum Acara Pidana (KUHAP), Undang-Undang Nomor 8 Tahun 1981.

Republik Indonesia, Peraturan Pemerintah Tentang Pelaksanaan Kitab Undang-Undang Hukum Acara Pidana, Peraturan Pemerintan Nomor 27 Tahun 1983.

Republik Indonesia, Peraturan Pemerintah Tentang Perubahan Atas Peraturan Pemerintah Tentang Pelaksanaan Kitab Undang-Undang Hukum Acara Pidana Nomor 27 Tahun 1883, Peraturan Pemerintah Nomor 58 Tahun 2010.

Republik Indonesia, Undang-Undang Tentang Dokumen Perusahaan Nomor 8 Tahun 1997.
Republik Indonesia, Undang-Undang Tentang Pemberantasan Tindak Pidana Korupsi Nomor 20 Tahun 2001 tentang Perubahan Atas Undang-Undang Nomor 31 Tahun 1999 tentang Pemberantasan Tindak Pidana Korupsi.

Republik Indonesia, Undang-Undang Tentang Pemberantasan Tindak Pidana Perdagangan Orang Nomor 21 Tahun 2007.

Republik Indonesia, Undang-Undang Tentang Informasi dan Transaksi Elektronik Nomor 11 Tahun 2008.

Republik Indonesia, Undang-Undang Tentang Narkotika Nomor 35 Tahun 2009.

Republik Indonesia, Undang Undang Tentang Pencegahan dan Pemberantasan Tindak Pidana Pencucian Uang Nomor 8 Tahun 2010.

Republik Indonesia, Undang-Undang Tentang Pencegahan dan Pemberantasan Tindak Pidana Pendanaan Terorisme Nomor 9 Tahun 2013.

Republik Indonesia, Undang-Undang Tentang Pencegahan dan Pemberantasan Perusakan Hutan.Nomor 18 Tahun 2013.

Republik Indonesia, Undang-Undang Tentang Hak Cipta Nomor 28 Tahun 2014.

\section{Jurnal}

Hanafi, Reza Aditya Pamuji. Urgensi Keterangan Ahli Sebagai Alat Bukti Berdasarkan Sistem Peradilan Pidana di Indonesia. Jurnal Al'Adl Volume 10 Nomor 1, Januari 2019. 
Isma, Nur Laili dan Arima Koyimatun. Kekuatan Pembuktian Alat Bukti Informasi Elektronik Pada Dokumen Elektronik Serta Hasil Cetaknya Dalam Pembuktian Tindak Pidana. Jurnal Penelitian Hukum Volume 1, Nomor 2, Juli 2014.

Sahuri, Lasmadi. Pengaturan Alat Bukti Dalam Tindak Pidana Dunia Maya. Jurnal Ilmu Hukum Volume 5 Nomor 2, Oktober 2014.

Sugiarto, Enan. Implikasi Putusan Mahkamah Konstitusi Nomor 20/PUU-XIV/2016 Terhadap Informasi Elektronik Dan/Atau Dokumen Elektronik Dan/Atau Hasil Cetaknya Sebagai Alat Bukti Dalam Perkara Perdata. Jurnal Rechtidee Volume 11. Nomor 2, Desember 2016.

\section{Prosiding}

Kadi Sukarna. 2014. Alat Bukti Petunjuk dalam Proses Peradilan Pidanal Prosiding Seminar Nasional: Pengembangan Epistemologi Ilmu Hukum). Surabaya : Untag 45.

\section{Website}

https://www.mahkamahagung.go.id/id/arti kel/3048/eksistensi-dokumenelektronik-di-persidangan-perdata. Diakses tanggal 01 Juli 2019 Pukul 10:24 WITA.

https://bh4kt1.wordpress.com/2016/10/03/ bukti-elektronikdigital-menurutputusan-mk/. Diakses pada tanggal 29 Juli 2019 Pukul 11:30 WITA. https://www.kompasiana.com/septiandwiri adi/592544145293739205cb67e4. Diakses pada tanggal 26 November 2019. Pukul 12.11 WITA. 